\title{
Different mucosal presentations of non-Hodgkin lymphoma: case series
}

\author{
Non-Hodgkin lenfomanın farkı mukozal \\ görünümleri: Olgu serisi
}

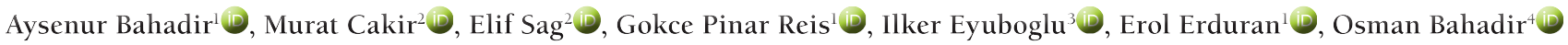
${ }^{1}$ Dept. of Pediatric Hematology, Karadeniz Technical University Faculty of Medicine, Trabzon, Turkey, ${ }^{2}$ Dept. of Pediatric Gastroenterology, Karadeniz Technical University Faculty of Medicine, Trabzon, Turkey, ${ }^{3}$ Dept. of Radiology, Karadeniz Technical University Faculty of Medicine, Trabzon, Turkey, ${ }^{4}$ Dept. of Otorhinolaryngology, Karadeniz Technical University Faculty of Medicine, Trabzon, Turkey
\end{abstract}

\section{Abstract}

Non-Hodgkin lymphoma has an incidence $8 \%$ of all childhood malignancies in the world. Non-Hodgkin lymphoma typically invades the liver, lungs, spleen and mediastinum. The most common symptoms include pain and coughing due to enlarged lymph nodes, shortness of breath due to thoracic masses, and bowel obstruction and acid in abdominal involvement. In this study, we have discussed cases of lymphoma with different mucosal presentations. The age of the patients varied from 3.5-16 years, and included three females and two males. The cases include patients with lymphoblastic lymphoma referring with a preliminary diagnosis of eosinophilic granuloma; with lymphoblastic lymphoma, with a preliminary diagnosis of odontogenic cyst; with Burkitt lymphoma, with lower gastrointestinal system bleeding-acute gastroenteritis; with Burkitt lymphoma, with a preliminary diagnosis of ovarian tumor and with diffuse large B-cell lymphoma, with a diagnosis of anemia. Clinical, laboratory and radiological diagnostic methods can guide diagnosis of lymphoma, histopathologic examination is important for the final diagnosis. In conclusion, it is important to make a systemic evaluation rather than focusing only on the referral complaints and radiological imaging in patient assessment.

Key words: child, lymphoma, bone, ovarian, gastrointestinal system

\section{O̊zet}

Dünyada çocukluk çă̆ı malinitelerinin \%8'ini non-hodgkin lenfoma oluşturmaktadır. Non-hodgkin lenfoma genellikle karaciğer, akciğer, dalak ve mediastinuma yayılır. En yaygın bulgusu lenf nodu genişlemesine bağlı ağrı, öksürük, torakstaki kitlelere bağlı nefes darlığı, abdominal bölge tutulumunda barsak obstrüksiyonu ve asit gibi bulgulardır. Biz burada farklı klinik ve radyolojik bulgularla gelip, lenfoma tanısı koyduğumuz hastalarımızı tartıştık. Hastaların yaşları 3,5-16 yıl arasında olup üç kız, iki erkekti. Eozinofilik granülom ön tanısı ile gelen lenfoblastik lenfoma, odontojenik kist ön tanısı ile gelen lenfoblastik lenfoma, alt gis kanama-akut gastroenterit

Corresponding author: Aysenur Bahadir, Dept. of Pediatric Hematology, Karadeniz Technical University Faculty of Medicine, Trabzon, Turkey. Phone: +90 46237754 40, E-mail: aysenurkbr@yahoo.com

Received: 27 July 2020 Accepted: 28 September 2020

Conflicts of Interest: None

Funding: None

How to cite this article: Bahadir A, Cakir M, Sag E, et al. Different mucosal presentations of non-Hodgkin lymphoma: case series. Mucosa 2020;3:69-74

(c) (i) (8) This work is licensed under a Creative Commons Attribution-NonCommercial 4.0 International License. 
şikayeti ile gelen Burkitt lenfoma, over tümörü tanısı ile gelen Burkitt lenfoma, anemi tanısı ile gelen diffüz büyük hücreli B-cell lenfoma tanılı olgularımızı rapor ettik. Lenfomanın tanısında klinik, laboratuvar ve radyolojik tanı yöntemleri yol gösterici olsa da patolojik doku tanısı kesin tanı için önemlidir. Hastalar değerlendirilirken sadece başvuru şikayetine, radyolojik görüntülemelere odaklanmayıp, sistemik odaklanılmamalı, sistemik olarak değerlendirme yapılmalıdır.

Anahtar kelimeler: çocuk, lenfoma, kemik, over, gastrointestinal sistem

\section{Introduction}

Non-Hodgkin lymphoma (NHL) has an incidence of $8 \%$ of all childhood malignancies in the world. There are four main categories of childhood NHL: Lymphoblastic lymphoma (LL), Burkitt lymphoma (BL), diffuse large B-cell lymphoma (DLBCL) and anaplastic large-cell lymphoma. ${ }^{1,2}$

This study involves patients who were presented with various clinical and radiological findings and who were diagnosed with lymphoma. The cases include patients with LL referring with a preliminary diagnosis of eosinophilic granuloma (EG); with LL, with a preliminary diagnosis of odontogenic cyst; with BL, with lower gastrointestinal system (GIS) bleeding-acute gastroenteritis; with $\mathrm{BL}$, with a preliminary diagnosis of ovarian tumor and with DLBCL, with a diagnosis of anemia.

\section{Cases}

This study included five cases with a rare NHL localization and/or a pre-diagnosis of non-lymphoma. Informed consent was obtained from parents.

\section{Case 1}

A 3.5-year old female patient was referred to department of neurosurgery upon the detection of a mass on a cranial computed tomography (CT) following a head trauma (Fig. 1). It was suspected to be EG. A biopsy specimen was identified as precursor B-cell LL, and the patient was referred to the pediatric hematology-oncology department. Upon the initial assessment of the patient, a mass was identified in the parietal bone at the level of the vertex, and increased kidney size and parenchymal thickness, and hypodense areas related to involvement of lymphoma were found on an abdominal CT. The patient was staged as stage III, and treatment was initiated according to the LMB-96 chemotherapy protocol. The patient's treatment is ongoing at $8^{\text {th }}$ months since diagnosis.

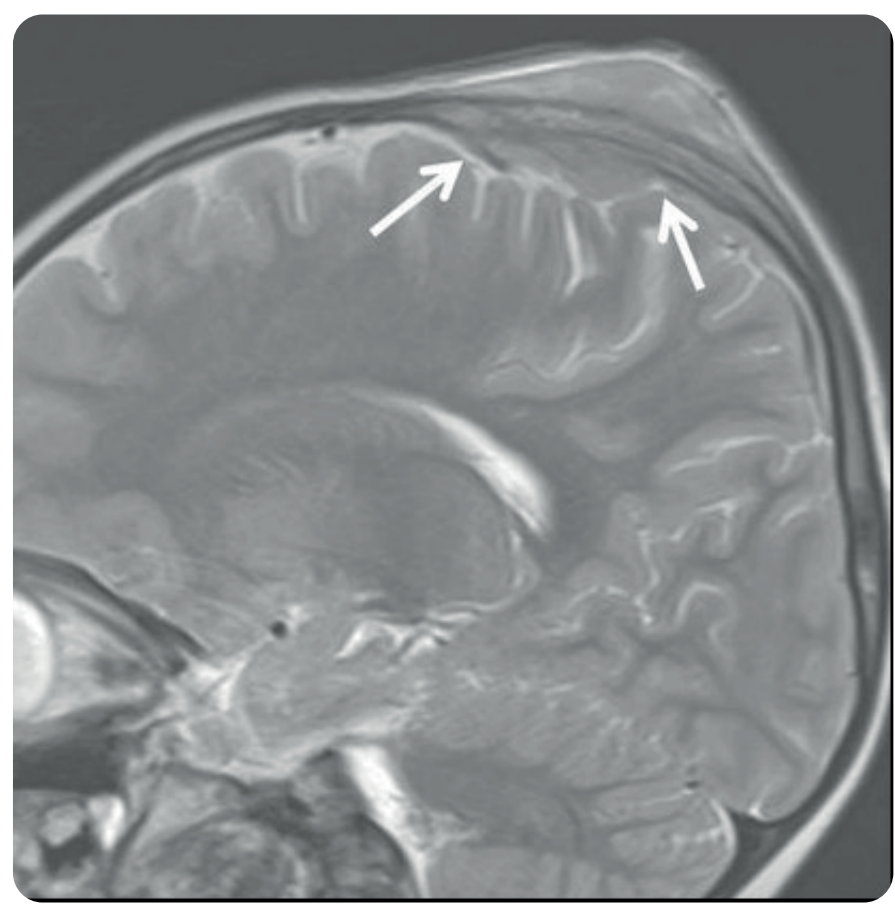

Fig. 1. A mass measuring $5 \mathrm{~cm}$ in diameter that had soft tissue components, and that extended into the intracranial, extracranial spaces, causing the erosion of the parietal bone at the level of the vertex in cranial CT

\section{Case 2}

An 8-year old male patient who complained of a swelling in a left upper tooth and cheek applied to a dentist about a month ago and a biopsy was performed by the maxillofacial surgery department after an odontogenic cyst was suspected. Histopathologic findings were consistent with LL, and the patient was referred to our department. Upon the examination of the patient, a hard mass was identified in the left upper palate, as well as facial asymmetry. A positron emission tomography (PET) revealed a mass lesion extending into the nasal cavity, filling the cavity of medial to the left 
maxillary sinus, and extending into the anterior to the inferior zygomatic bone. The patient was evaluated as stage III, and the BFM-2009 treatment protocol was initiated. The patient is in remission with the maintenance treatment.

\section{Case 3}

An 8-year old male patient consulted a physician about 45 days earlier with complaints of abdominal pain, vomiting and diarrhea. Acute gastroenteritis was suspected and the patient began the appropriate treatment. After complaining of intermittent bloody stool and severe abdominal pain over the previous one month, he was admitted to the pediatric surgery service, where a physical examination, upper gastrointestinal endoscopy, and abdominal ultrasonography (USG) was normal. One week later, however, the patient referred to the pediatric gastroenterology department with continued abdominal pain. A 5x6 cm mass lesion was observed in the transverse colon during a colonoscopy, and a biopsy was performed (Fig. 2). The biopsy findings of the patient was consistent with BL. The PET report of the patient showed involvement of the lymph nodes in the bilateral axillary region, and in the bowel segment and its adjacency in the abdomen.
The patient was evaluated as stage III, and the LMB96 treatment protocol was initiated. The treatment of the patient has recently completed, and he is under follow-up in remission.

\section{Case 4}

A 9-year old female patient referred to hospital with abdominal distension. The patient was told she had gas and left without treatment. The complaints continued and increased at follow-up, and she referred to the department of gastroenterology, where a USG revealed a hypoechoic solid mass lesion on the adnexal sides. The patient was consulted to pediatric hematology-oncolgy departemnt for the suspected ovarian mass. The patient had undergone a liver transplantation with a diagnosis of progressive familial intrahepatic cholestasis when she was 6.5 months old. There was a massive pleural effusion on the left side, found on thoracic CT, a solid cystic mass in the right and left adnexal areas, and acid in the abdomen upon an abdominal CT (Fig. 3). Alpha-fetoprotein, and beta-HCG were normal and CA125 was $1088.4 \mathrm{U} / \mathrm{mL}$ (0-35). The patient was diagnosed as $\mathrm{BL}$ according to the biopsy findings. For the patient at stage III, the LMB-96 treatment protocol was initiated. The treatment of the patient has comple-

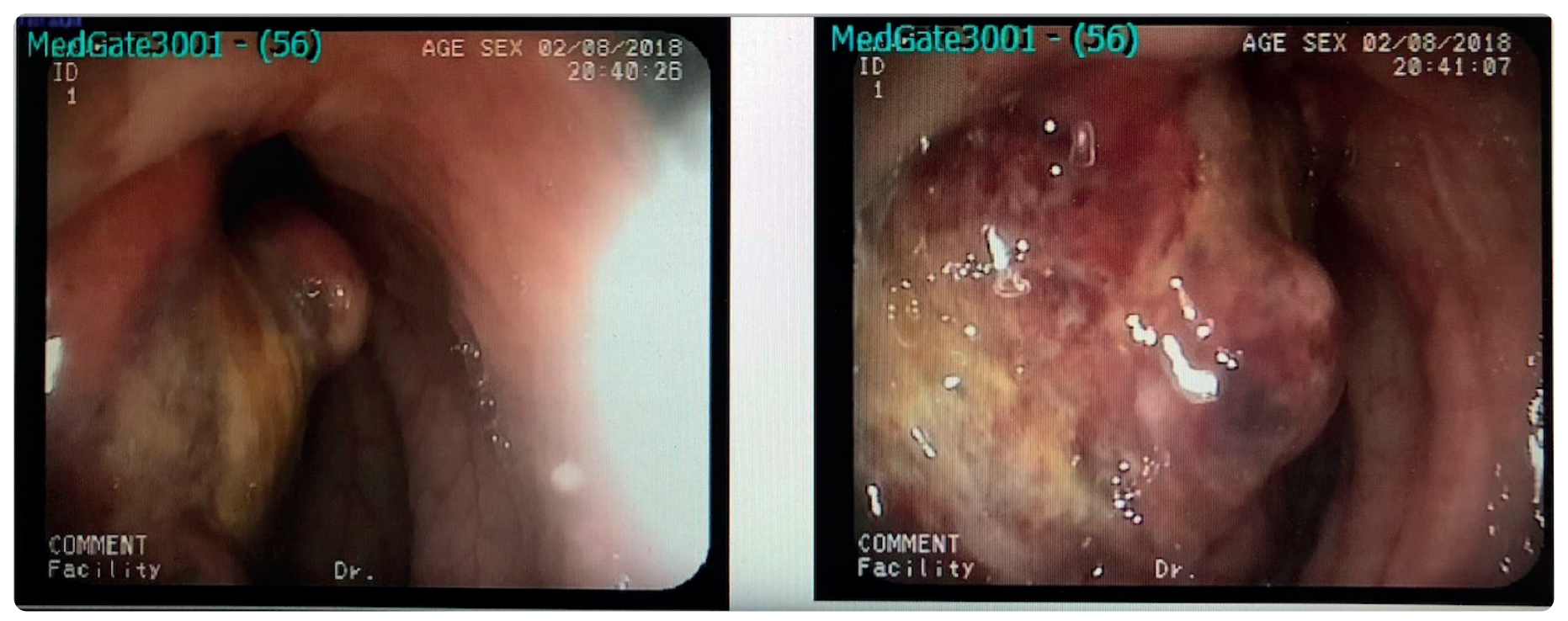

Fig. 2. A $5 \times 6 \mathrm{~cm}$ mass lesion in the transverse colon 

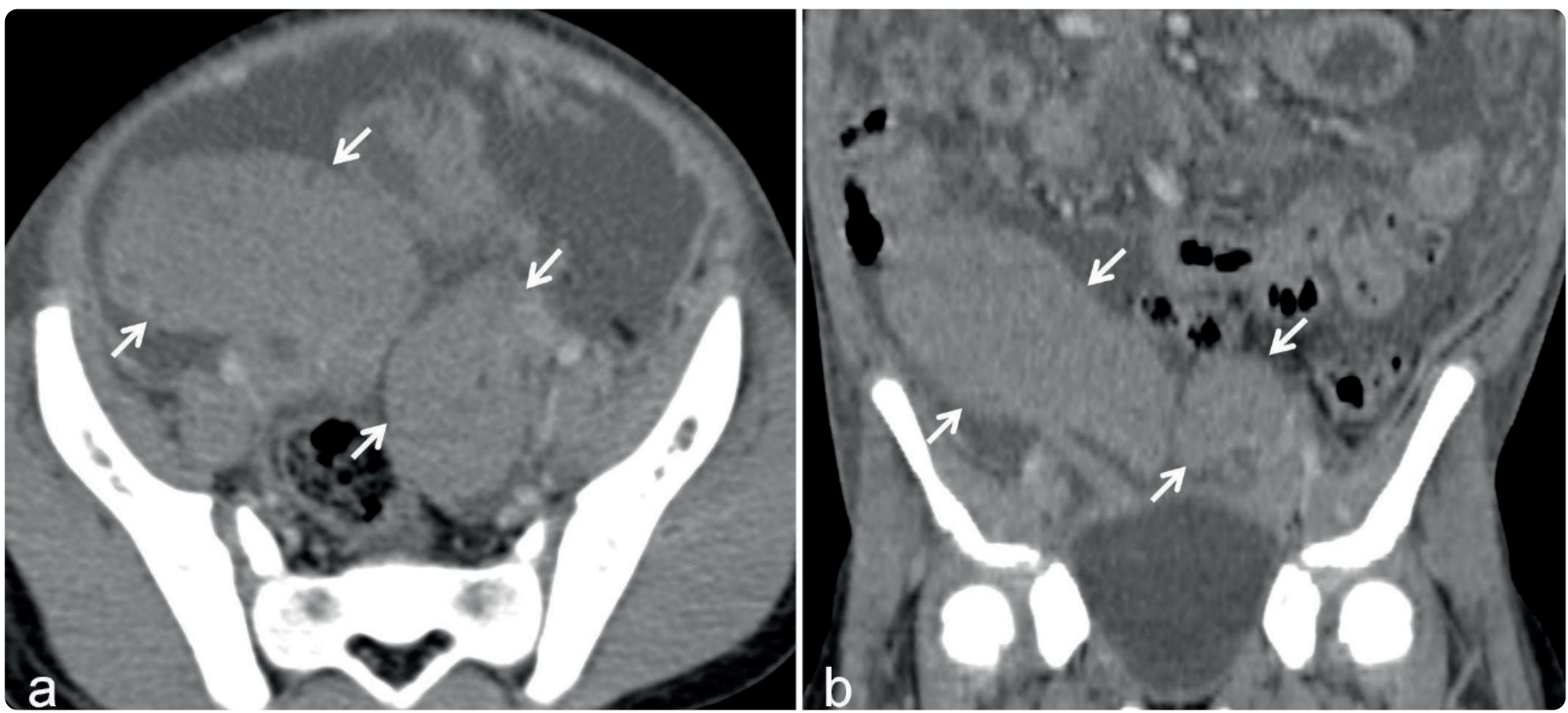

Fig. 3. A $80 \times 48 \mathrm{~mm}$ and a 46x $28 \mathrm{~mm}$ solid cystic mass in the right and left adnexal areas in abdominal CT

ted, and she is under follow-up in remission.

\section{Case 5}

A 16-year old female patient consulted a physician with loss of appetite, vomiting and nausea, about 3 months before referring to our department. It was ascertained that she had been undergoing irregular iron therapy due to anemia for the last one year. During an upper gastrointestinal endoscopy, a mass lesion was identified in the whole stomach and a biopsy specimen was taken from the site. The biopsy result of the patient was reported as DLBCL. For the stage III patient, the LMB-96 treatment protocol was initiated. The treatment of the patient has completed, and she is under follow-up in remission.

\section{Discussion}

NHL typically invades the liver, lungs, spleen and mediastinum, with rare involvement of bone marrow and the central nervous system. The most common lymphomas are BL and DLBCL, and the most frequent complaints are abdominal pain, loss of weight, and ileus. ${ }^{1-3}$ In the present study, two of the five patients were BL and one was DLBCL.
The DLBCL-diagnosed patient in the present study had iron deficiency anemia that did not improve despite treatment. The most common cause of anemia during puberty (age 12-18) is loss of blood through menstruation for girls, vegetarian diet, malnutrition, weight-loss diets and eating disorders, although anemia may also be caused by peptic ulcer, polyps, inflammatory intestinal diseases and parasitic infections that cause blood loss. ${ }^{4}$ Primary NHL occurs very rarely in the gastrointestinal system, and has been reported to account for $1-4 \%$ of all gastrointestinal malignancies. Patients present with non-specific symptoms such as abdominal pain and weight loss. ${ }^{2,5}$

BL is a highly aggressive and curable type of lymphoma, with one-third of cases diagnosed between the ages of five and nine. The endemic type BL usually occurs as a result of Epstein-Barr virus (EBV) infection and most frequently involves the jaw bone. The non-endemic type BL, involves extranodal regions, or the intestinal tract, mesentery, kidneys, liver, central nervous system and gonads. The ileocecal region is the most common site of involvement. ${ }^{2}$

Case 3 presented with abdominal pain and bloody 
stool. The most common causes of childhood lower gastrointestinal bleeding are anal fissures, allergic colitis, enteric infections and juvenile polyps. ${ }^{6}$ In the present case, it was initially considered to be related to infection, since the lower GIS bleeding was accompanied by diarrhea. When the complaint continued a colonoscopy was performed and the BL diagnosis was established.

In case 4 a primary ovarian BL developed eight years after a liver transplantation. The initial diagnosis was Meigs syndrome or malignant ovarian tumor due to the presence of ovarian involvement and abdominal and pleural fluid, along with high levels of CEA. Meigs syndrome is characterized by the co-existence of pleural effusion, acid and benign ovarian tumors, and the improvement of pleural effusion and acid following the resection of the ovarian tumor. CA 125, in turn, is typically elevated in malignant ovarian tumors. ${ }^{7}$ Primary ovarian $\mathrm{BL}$ is rare, being observed only in $0.5 \%$ of NHL cases, and this rarity is attributable to the lack of lymphoid tissue in the ovaries. Literature contains only a limited number of reports on bilateral ovarian BL in patients under the age of $20 .{ }^{8,9}$ Nevertheless, the risk of NHL is 100 times greater in organ transplant patients than in the general population. ${ }^{10}$

Childhood LL has an incidence of $30 \%$, with $15 \%$ of this being precursor B-cell LL. Precursor T-cell LL presents with painful LAP and a mediastinal mass, while precursor B-cell LL is likely to involve the skin, lymph nodes, and less frequently, bone and mediastinum. ${ }^{1,2}$ Case 1 referred following a head trauma and the patient was operated on based on an initial diagnosis of an EG. EG is a member of Langerhans-cell histiocytosis group, and most commonly occurs in children aged 5-10 years old. It is typically localized in the ribs, pelvis, mandible and the metaphysis of long bones, and is radiologically viewed as a lytic lesion. It may rarely involve soft tissue. It may be clinically asymptomatic or may present with local pain. ${ }^{11}$ Upon the identification of stiffness in the maxillary region in case 2, a biopsy specimen was taken due to suspicions of an odontogenic tumor. Keratocystic odontogenic tumors are the most common benign tumors of the maxillofacial region. They can occur at any age, but are most common in the 2 nd or 3rd decades of life. ${ }^{12}$ In our case, there was a bone involvement of a precursor B-cell LL. Oral lymphomas are very rare, and occur rarely in the palate, gingiva, tongue and buccal mucosa. ${ }^{13}$

In this study we have discussed cases of lymphoma with different presentations. Although clinical, laboratory and radiological diagnostic methods can guide lymphoma diagnoses, pathological tissue is important for the final diagnosis. As in the cases in the present study, patients may refer initially to different departments and may receive various preliminary diagnoses. In conclusion, in patient assessment, it is important to make a systemic evaluation rather than focusing only on the referral complaints and radiological imaging.

\section{References}

1. Javed Z, Hanif F. A rare presentation of precursor B-cell lymphoblastic lymphoma in a child. Cureus 2018;31:10:e3238.

2. Martin-Guerrero I, Salaverria I, Burkhardt B, et al. Non-leukemic pediatric mixed phenotype acute leukemia/lymphoma: Genomic characterization and clinical outcome in a prospective trial for pediatric lymphoblastic lymphoma. Genes Chromosomes Cancer 2019;58:365-72.

3. Kolve M, Fischbach W, Greiner A, Wilms K. Differences in endoscopic and clinicopathological features of primary and secondary gastric non-Hodgkin's lymphoma. German gastrointestinal lymphoma study group. Gastrointest Endosc 1999;49:307-15.

4. Powers JM, Buchanan GR. Disorders of iron metabolism: New diagnostic and treatment approaches to iron deficiency. Hematol Oncol Clin North Am 2019;33:393-408.

5. Soyer N, Yilmaz AF, Ozsan N, et al. Retrospective analysis of primary gastric diffuse large B-cell lymphoma: a single center study from Turkey. Turk J Med Sci 2017; 47:240-5.

6. Barnert J, Messmann H. Management of lower gastrointestinal tract bleeding. Best Pract Res Clin Gastroenterol 2008;22:295-312. 
7. Kasap E, Genc M, Korkut B, Sahin N, Demir S. Meigs' syndrome with elevated serum CA125: Case report. Journal Of Contemporary Medicine 2016;6:114-7.

8. Akakpo PK, Derkyi-Kwarteng L, Quayson SE, Gyasi RK, Anim JT. Ovarian tumors in children and adolescents: A 10-Year histopathologic review in Korle-Bu Teaching Hospital, Ghana. Int J Gynecol Pathol 2016;35:333-6.

9. Lee AC, Chui CH. Bilateral ovarian Burkitt's lymphoma: Successful treatment with preservation of ovarian function. J Pediatr Adolesc Gynecol 2015;28:105-7.

10. Yanik EL, Shiels MS, Smith JM, et al.Contribution of solid organ transplant recipients to the pediatric non-Hodgkin lymphoma burden in the United States. Cancer 2017;123:4663-71.

11. Bertram C, Jurgen M, Eggers C. Eosinophilic granuloma of the cervikal spine. Spine 2002;27:1408-13.

12. Chrcanovic BR, Gomez RS. Recurrence probability for keratocystic odontogenic tumors: An analysis of 6,427 cases. J Craniomaxillofac Surg 2017;45:244-51.

13. Alli N, Meer S. Head and neck lymphomas: A 20-year review in an oral pathology unit, Johannesburg, South Africa, a country with the highest global incidence of HIV/AIDS. Oral Oncol 2017;67:17-23. 